\title{
Understanding Leadership and Factors that Influence Leaders' Effectiveness
}

\author{
Kemal M. Surji PhD, RRT, HA \\ Hawler Medical University, College of Pharmacy
}

\begin{abstract}
The aim is to simplify the subject of leadership in a most understanding fashion. Furthermore, it clarifies the steps in leadership design and characteristics associated with it. The subject composed of ten letters, each representing a powerful word that develops the most admired topic in the modern day organizations called "LEADERSHIP." The words that characterize the subject are: listen, enthusiasm, aspiring, decisiveness, empowerment, responsible, supportive, humble, and inspiring as well as planner. Thereby, leadership is defined as a position to listen with enthusiasm, having an aspiring mind to be able to make a decisive action, empower and encourage others in a responsible, supportive and humble manner to inspire them to achieve set goals as planned." Those adhering to these influential words become an effective leader in any situation. The article also displays the most damaging phrases the real leaders should never utilize. Additionally, the five levels of becoming a great leader discussed in detail such as position, permission, production, development, and lastly the pinnacle as the highest level of leadership. Leadership is influence; therefore, becoming a real leader requires the right attitude and behavior in dealing with people in any organization or society.
\end{abstract}

Keywords: attitude, behavior, damaging words, influence, Leader, leadership, levels, powerful

DOI:

10.7176/EJBM/7-33-2015-03

\section{INTRODUCTION}

This review article is to provide simple steps in understanding leadership and behavior modification that will help executives and managers grasp and acquire the maximum benefit from the subject of leadership.

Leadership is a significantly popular and highly appreciated topic. For many years, people and organizations have become increasingly interested in the idea of leadership seeking more information on how to become great leaders. Consequently, a tremendous number of books, research articles, and training as wells as workshops have been published on the subject of leadership. It is believed that leadership is a way to enhance personal growth, social and professional advancement (Northouse, 2010).

Organizations believe that leadership ability brings valuable assets to their establishments thus improve growth and revenue. Therefore, organizations around the world spend billions of dollars on the subject of leadership training and development. These instructions take many forms such as expensive programs offered by universities that have established majors in leadership to serve the demand of the society for becoming an effective leader. Moreover, costly seminars designed for organizations to teach executives and managers how to become better leaders (Robbins, Coulter, 2009).

Even though the subject of leader and leadership should not be as complicated as it seems, the researchers have created complexity to the point of confusion among people that makes learning difficult and demotivate people on that subject. Also, much of the money spent on leader training may have provided doubtful benefits.

Previously there have been numerous classifications and definitions of leadership such as traits and characteristics, focus group process, act or behavior, a power relationship, transformational process as well as skills perspective. Despite the above, multiple confusing concepts, the following components will simplify the meaning of an effective leader. First, the words lead, leader, and leadership must be identified. Secondly, the characteristics of leader and leadership will be described in a simple concept.

The word "lead", according to the Webster dictionary, means "to guide on a way." Moreover, "leader" is defined as "a person who leads and has commanding authority or influence". Furthermore, "leadership" is described as "a position as a leader of a group, organization, or an institution. The authority or ability to lead other people". 
Based on the above definitions, the leadership is a method whereby an individual influences a team to achieve a common goal. Therefore, leadership is not only influence but also does not exist without influence. The leadership factors that create impact are within the letters that form the word leadership as follows:

\section{“LEADERSHIP"}

- $\quad$ L: Listen - leaders listen to communicate effectively. Great leaders are great listeners; therefore, they speak less and listen more.

- E: Enthusiasm - Great Leaders show great excitement for achievements.

- A: Aspiring - Leaders having high ambitions and goal thriving to achieve with an enormous desire

- D: Decisive - To make tough decisions and be accountable.

- E: Empower and Encourage - Give a greater responsibility to people and give them the support they need

- $\quad$ R: Responsible - Ability to take responsibility for actions

- S: Supportive - helps to build and maintain effective interpersonal relationships. A manager who is thoughtful, caring and friendly toward employees is more likely to win their friendship and loyalty.

- H: Humble - A humble, honest leader, tries to elevate everyone with his humility and makes other to feel important and valued

- I: Inspire with Integrity - Encourage, Motivate others with honesty and truthfulness.

- P: Plan - Great leaders are excellent at strategic planning. They have the capacity to plan ahead, and create a contingency plan (Plan-B) in case plan-A did not go as intended.

Based on the above factors the leadership defined as:

" $\mathrm{L} \rightarrow \mathrm{E} \rightarrow \mathrm{A} \rightarrow \mathrm{D} \rightarrow \mathrm{E} \rightarrow \mathrm{R} \rightarrow \mathrm{S} \rightarrow \mathrm{H} \rightarrow \mathrm{I} \rightarrow \mathrm{P}$ : Is a position to Listen with Enthusiasm, having an Aspiring mind to be able to make a Decisive action, Empower and Encourage others in a Responsible, Supportive and Humble manner to Inspire them to achieve set goals as Planned."

The most successful leaders can communicate their organization's mission and express it in ways that inspire others to attain it; however, other traits, behaviors, and skills are required for leadership. Leaders must treat others as they would like to be treated. Therefore, leaders must avoid certain words and phrases that might be damaging to others. For example, the following phrases and statements are considered destructive and potentially causes harm to team members:

- "I am in charge or the boss,"

- "You are lucky to have this job,"

- "I want results, not relationships,"

- "I know everything,"

- "That is not my fault,"

- "I'll do it myself,"

- "Failure is not an option,"

- "That is not the method we use around here,"

- "I do not care,"

- "It is impossible."

When the person of authority uses these expressions, it can generate an adverse effect and deter the primary factor of leadership known as an influence (Smith, 2014).

According to John C. Maxwell, there are different stages of leadership or the 5-Ps of leadership. Therefore, one cannot become an effective leader unless they go through these phases in order it is given:

1. Position (Right), the entry level, people follow because they have to.

2. Permission (The Relationship), the Influence Level, people follow because they want to.

3. Production, Result level, people follow because of what the leader has done for the organization.

4. People development, Re-Production Level, people follow because of what the leader has done for them. 
5. Pinnacle, Respect Level, people follow because of who the leader is and what he or she represents.

This study identifies the ten factors of an effective leader, the negative phrases that leader must never use when speaking to their team and also the levels of leadership that every individual seeking leadership must adhere to become an effective leader in the society.

\section{Statement of Problem}

For decades, people are searching for the solution to better lead and enhance leadership to suit a society or an organization. Numerous research studies and books have been published in describing and fine tuning the concept of leadership styles and effective leader. However, none of which have been a robust method of achieving the perfect result, instead causing tremendous expenditure for many organizations and institutions. Many individuals see leadership as a position of power and authority while others perceive it as culturally dependent at the same time others believe leadership is an influence.

The study will present the ten letter word in which each letter relates to a concept that describes the behavior of a real leader that is practical and relates to human nature. Following the ten letter theory will enhance and modify the attitude and behavior of any individual to become an influential leader of a team, organization or society.

\section{Study Objectives}

The following objectives illustrated for the enhanced understanding of the study

- $\quad$ To comprehend the word lead, leader and leadership

- To understand the concept of leadership

- To understand the ten factors, that makes up leadership.

- To gain effective leadership behavior

- To recognize hurtful words

- To learn the five levels of leadership

\section{Significance of the Study}

Leadership quality is a vital factor for any nation, organizations, families and individuals. Effective leadership assists the country through times of threat. It also attribute to the success of the business organization and enables nonprofit organization to achieve its mission. The parent's effective leadership skills allow children to mature stay healthy and become productive adults and active member of society. Therefore, this study will concentrate on factors that best attribute to developing a quality and effective leader to assure absolute success in any leadership position.

\section{Literature Review}

One can learn leadership at the same time the power is developed; however, to be an effective leader, one must be able to differentiate from the numerous methods of control and choose the form that most harmonized with his or her leadership style, character traits, and working environment.

Leadership is a manner by which an individual influences the thoughts, attitudes, and behaviors of others. Leaders set a direction for the team; they help people see what lies ahead; they assist staff to visualize what they might achieve; they encourage and inspire the society. Without leadership, a group of human beings quickly degenerates into argument and conflict, because we see things in different ways and lean toward different solutions. Leadership helps to point us in the same direction and harness our efforts jointly. Leadership is the ability to get other people to do something significant that they might not otherwise do. It is energizing people toward a goal (Mills 2005). 


\section{Real Leaders "Listen."}

The first rule in communication is to seek to understand before trying to be understood. Listening requires leaders to know that staff is essential. Listening must be the highest priority of an active leader (Rynders 1999). We have been given two ears and only one mouth, to listen more and speak less. In reality, however, only half of our communication is spent in listening. Success at all levels of management may depend on how well we listen to detailed instructions or to feedback from our staff (Atwater, 1992). According to Hunsaker and Alessandra, of all the sources of information to aid managers recognize and assess the personalities of their department members, listening to the individual employee is the utmost significant (1986).

Leadership is almost exclusively a communication activity. Indeed, effective leaders communicate clearly, promptly, empathically, and they keep team members well-versed. Real leaders "walk the talk" by delivering what they promise (Rosenbach et al. 1996). The two expressive qualities of effective leaders are identified as active listening and sympathizing with what people have to say (Rynders 1999). Leaders know how to listen and possess essential qualities that encourage positive work relations, inspire trust, and augment the result. Effective leaders know people have a necessity to be heard. Empathy is as appreciated as the willingness to listen, noted by Lucia (1997).

Most importantly, a leader listens well to the concerns and problems of people and ensures they are addressed to build a real win-win affiliation for all parties involved.

\section{"Enthusiasm" as a Principal Characteristic of an Effective Leader}

Enthusiasm is one of the vital features that define the leader. Enthusiastic leaders obtain superior outcomes from their team members. Being a leader is challenging and rewarding at the same time. Enthusiasm is a core characteristic of being a successful leader. Enthusiasm is exceedingly contagious. It is proven when people work with an enthusiastic leader; they find themselves imitating their attitude and conduct (McCann, 2011).

Hsin-Yi Cohn in an online article in the title of "Characteristics of Good Leaders," indicate that genuine enthusiasm is infectious. Moreover, good leaders who are enthusiastic about their work and their role as a leader will be able to use their passion to motivate other members of their team. Enthusiasm also indicates being as part of the team, working towards a mutual goal and not just a "big boss" ordering others around (Cohen, 2015).

\section{Good Leaders are "Aspiring."}

Noble leaders have high ambitions and goals as they thrive to achieve with an enormous desire. In an online article by The Team of Distinction in the title of, "GREAT LEADERS UNLEASH THE POWER OF ASPIRATION," points out that the force of desire has been explained in a simple and comprehensive fashion. The article indicates that aspirational spirits are established by cunning leaders who realize the nature of people. Leaders also know that to create something beyond the ordinary requires focusing people on the extraordinary. John F. Kennedy in his announcement speech elucidates aspirational ambitions in the challenge to reach the moon saying "We do not do it because it is easy. We do it because it is hard. We do it because that goal will serve to organize and measure the best of our energies and skills". That is the purpose of an aspirational ambition (http://teamsofdistinction.com/great-leaders-unleash-the-power-of-aspiration/).

Great leaders use a well-designed aspirational motivation that energizes the team and gives them the willpower to succeed all encounters they may potentially experience. A perfect example of the aspiration came from Martin Luther King speech when he spoke of dreaming of a time when people are judged by the content of their character, not by the color of their skin; he referred to the essence of the black Americans dreams and struggles. That is the idea and the fact of an aspirational determination. To focus people on one clear goal that enables everyone to rally together.

Great leaders use an aspirational determination to encourage their teams to achieve the inconceivable. The main point is, when the team starts reaching what seemed unimaginable and unattainable, members develop a great 
sense of pride. The capability of the team to achieve the goal lets employees see that they are part of something very special. Therefore, attaining such success paves the road to breeds more achievements.

\section{The Decisive Leader:}

It is essential for leaders to be decisive since they are often called on to make significant decisions. A decisive leader judiciously assesses the possible effects of each decision and selects the prospect that works for his or her team. A decisive leader is responsible and feels contented for the outcome of his or her decision (http://www.leadershipandinfluenceblog.com/10-traits-of-effective-leaders/).

People are more inclined to follow a leader's aspirations if he or she appears decisive. According to Ray Miller, the author of "That is Customer Focus!," Management Training by the Book I, a leader assures he or she fully comprehend all alternatives before making or endorsing a decision. A real leader makes difficult decisions promptly that is rationally consistent with the business priorities and core beliefs of the company or department. Moreover, effective leader converses a justification for the decision. A leader escalates issues when a particular decision is out of his/her jurisdiction.

According to Mark Sanborn (2012), it is not necessarily more decisive rather being more knowledgeable to make a decision. The delinquency relates to not understanding the problem or situation, not having a well-developed plan in creating options to consider in addressing the issues. The leader must identify and define the issue then look for the opportunity the problem might present thereby ask the team members for the options and suggestions. After collecting many choices and options pick the solution that offers the best long-term resolution (Sanborn, 2012).

Peter Economy published an article on January 24, 2014, in the title of "The 9 Traits That Define Great Leadership," indicates that all leaders must make tough decisions for the benefit of the entire organization, judgments that require a firmness, authority, and finality that will not please everyone. Extraordinary leaders also know when not to act unilaterally but instead foster collaborative decision making. (Economy, 2014)

\section{Influential Leaders Empower and Encourage Team members}

Empowering employees is to share power with team members to influence the actions of the organization, since they contribute to overall performance and that their talent and experience is valued (MacDonald, 2011). Empowerment gives members a greater freedom and autonomy in the scheme of their work as well as exclusive responsibility for making decisions that have a direct impact on them. An effective leader that empowers and supports the team members displays trust in members' judgment, thereby encouraging the best performance. Effective leaders offer team members the authority and respect they need to perform their jobs well (http://www.leadershipandinfluenceblog.com/10-traits-of-effective-leaders/).

According to an article, The Power of the Powerful is to Empower the Powerless, posted on June 13, 2011, by Bob MacDonald, the leader must first comprehend the meaning of empowering before seeking employee empowerment. Some leaders are under the misapprehension that enabling others may result in loss of power of their own. Just the opposite is true, in fact, more power is gained by empowering others. MacDonald indicates that the real essence of empowering employees is not relinquishing power, but in sharing the benefits of power which creates influence within the organization and being in a position to make a difference (MacDonald 2011).

\section{Great leaders are Responsible}

As quoted by Henry A. Kissinger, "Leaders are responsible not for running public opinion polls but for the consequences of their actions." One of the essences of leadership skills is responsibility. Hopkin believes that accountability and integrity are adjoined. Leadership responsibility and acting with integrity is attained through accepting fault in a situation when something goes erroneous, taking responsibility for solving difficult problems, and learning how to stay composed and troubleshoot when things do not go as planned (Hopkin, 2015).

According to an article posted by Geoffrey Webb, (2010), THINGS LEADERS NEED TO TAKE, leaders are accountable for their action and the act of others in the team. People may not always experience the 
consequences, but they are still liable for what they do. Therefore, leader assumes the responsibility and culpability for the actions of other people. Again, it is not something that is given; it is taken (Geoffrey Webb, 2010).

Michael Hyatt in his article indicates that leaders accept responsibility for the outcomes (both good and bad) expected of them. Leaders do not blame others, and they do not blame the external environment. There are always things they could have done or still can do to change the outcome. Until leaders take responsibility, they are the victim and being a victim is the exact opposite of being a leader. Victims are passive since they are being used. Leaders are active that take the initiative to influence the outcome (http://michaelhyatt.com/leadership-andaccountability.html)

\section{Leaders are Supportive}

A real leader is a collaborator and act as a part of the team; thereby members will feel supported in their activities. Effective leaders are available to assist and sympathize with the team members by understanding exactly how they feel. Additionally, supportive leaders value their people by genuinely caring for them as an individual as well as recognizing their interests, strengths and goals (Eikenberry K., 2010).

There again listening as one of the characteristics of a leader is considered as one of the most contributory factors in leadership. When a person in a position of leadership listens effectively to the team members, he or she displays value and cares about their feelings and opinions. Supportive leaders give positive feedbacks and makes individual team members feel good about themselves, work situation as well as their life in general (Eikenberry K., 2010).

By displaying the supportive behaviors in a genuine, authentic way the leaders inspire and support people to develop into the very best member of the organization. Moreover, that is the responsibility of an unpretentious leader (http://blog.kevineikenberry.com/leadership-supervisory-skills/eight-supportive-behaviors-every-coachand-person-should-use/\#sthash.Y7US37ey.dpuf ).

\section{Great leaders are Humble with Humility}

As Doug Guthrie in his article points to the fact that the dictionary describes humility as modesty and lacking in pretense, but that does not mean humble leaders are submissive or timid. A humble leader is confident and recognizes his or her weaknesses. Leaders who cultivate humility seek the input and talents of others and are not guilty of demeaning their associates or rivals to glorify themselves. Humble leaders are self-assured; they inspire others to utilize their aptitudes and to pursue accomplishment to serve the organization and its mission (Guthrie, D., 2012).

Leaders with humility recognize that they are the same as others in the team no better or worse than other members. A humble leader is not modest but rather tries to uplift everyone on the team. Leaders with humility also acknowledge that their position does not make them a superhuman. Mahatma Gandhi is a paradigm for Indian leaders, and he trailed a "follower-centric" leadership character (Top 10 Leadership Qualities, 2014). Effective leaders are pragmatic and easy to approach. Team members feel more comfortable connecting with a humble and compassionate leader. Right leader attempts to know their team members and understand their background and keep a healthy, grounded perspective on his or her accomplishments (http://www.leadershipandinfluenceblog.com/10-traits-of-effective-leaders/).

\section{Great Leaders Inspire with Integrity}

According to Susan M. Heathfield, inspiring leaders are passionate about the mission, purpose and listen to their team members. Telling the truth and being trusted by team members create integrity. Inspirational leaders praise their team; includes them in the decision making and share the rewards besides notices individual's contributions to the success of the organization (http://humanresources.about.com/od/leadership/a/leader_inspire.htm). 
Inspirational leaders have Integrity that is the combination of external actions and intrinsic values. A person of integrity has the external action based on the internal values. Such an individual can be trustworthy because he or she never deviates from the moral standards. A leader must be trusted by the followers, and must display integrity. Sign of integrity includes: honest dealings, reactions that are certain, well-controlled feelings, and an absence of irritabilities and cruel outbursts, thereby, A leader who is integrity-centered will be more approachable by followers, (http://www.comparebusinessproducts.com/briefs/top-10-leadership-qualities).

A leader with integrity is truthful and open with his team members build the trust of people. A real leader does what he says he will do and treats others the same way he wants to be treated (http://smallbusiness.chron.com/10-effective-qualities-team-leader-23281.html).

\section{Great Leaders Develop Great Plans}

Great leaders are exceptional at strategic planning formulation. They have the aptitude to look into the future, to anticipate with some accuracy where the industry and the markets are heading. Leadership provides the linkage between planning formulation and implementation. Strategic planning is both a logical, rational process and a method that involves people for achieving set goals (http://work911.com/articles/leaddo.htm).

Planning and organization utilize consistent, efficient, systematic and precise measures to meet objectives. Great leaders create and use a robust planning and organization to safeguard against what might happen, and to respond to the unknown. Workplace Planning and organization helps keep team members accountable and stay on track (http://www.thecompleteleader.org/planning-organizing).

The literature indicates that leadership requires certain qualities to sustain and influence the followers in a positive manner. Effective leaders must be good listeners to develop a positive relationship and build trust. Enthusiasm is an essential characteristic of leadership that motivate team members and indicates being part of the team working toward a common goal. An aspiring leader creates an environment that inspires people to achieve beyond expectation. Leaders make difficult decisions promptly that is logically consistent with the business priorities and core values of the company. A real leader that empowers and supports the team members displays trust in members' judgment, thereby encouraging the best performance. Leaders take responsibility for the team's action and don't blame others or the external environment. Supportive leaders value their people by genuinely caring for them as an individual as well as recognizing their interests, strengths, and goals. A humble leader is self-confident and not self-effacing but rather tries to elevate everyone. Leaders who retain integrity attain the trust of team members as they do what they say and treat people the same manner they want to be treated. Great leaders create and use a robust planning and organization to safeguard against what might happen, and to respond to the unknown. Besides the above positive qualities of effective leaders, there are certain phrases that can be very damaging to a leader and leadership position:

\section{Damaging Words, Phrases or Statements, the Best Leaders Must Avoid}

Jacquelyn Smith presents the writing by Darlene Price, president and the author of Well Said, Inc., in regards to the importance of the spoken words that can seriously affect leaders' ability to achieve success (2014). Price says that successful leaders pave the road in inspiring others to achieve the organization's mission. However, there are other required qualities, behaviors, and talents for leadership, such as the power of spoken words placed on the top of the rank. Successful leaders recognize the influence of spoken words and phrases as well as its impact on emotions and minds of society. Consequently, good leaders commonly use positive and optimistic phrases when speaking with their team members, such as: "I want to thank you for....", "Our team's mission is....," "I like to hear your opinion", You are a vital part of the team because...," "How may I assist?", "as a team we can accomplish....", "Congratulations on your accomplishments." On the contrary, there are particular phrases that can be harmful to the individual or a group that an influential leader would never mention (Price, 2012). According to Price, there are ten important phrases that are considered the most damaging. Therefore, leaders should refrain in using them: 


\section{1. "I am in charge, or I am the boss."}

By stating this phrase, the leader denies the fact that he or she is the boss. It also weakens the leader showing low self-confident. Therefore, if everyone on the team acknowledges the fact one is the boss, it should not require a reminder. On the other hand, a real leader would use his or her authority to empower and encourage others to respect and follow. Efficient and influential leaders are well respected; thereby, must ask questions such as 'What is needed for success?' or, 'how can I assist to achieve the objectives?'

\section{2. "You are lucky to have a job here."}

Price states such spoken phrase by a leader takes the motivation out of an employee and destroys morale. The statement suggests the leader doing people a favor by employing them, and they are indebted for the privilege of working for him or her. Instead, a real leader would use a statement like, "We are lucky to have you on our team" (2012). Price also indicates that words and actions of great leaders inspire others to have a greater vision, pursue higher learning, provide and grow more. As John Quincy Adams said. "That is why they are seen as leaders, the combination of their communication and character induce people to follow. The best leaders deliberately choose particular words to say, and not say, in order to maximize their ability to achieve results through people" (2012).

\section{3. "I want results, not relationships."}

Effective leaders are aware that people produce results; therefore, it is imperative to build robust associations with employees, fellow managers, customers, business partners, vendors, and other key stakeholders. The relationship comes before result (Price 2012). Hence, build the relationship and result will follow.

\section{I know everything - I have thought of everything.}

A leader with knows it all attitude that looks down on subordinates is not a real leader. An effective leader always listens and continues to improve and remains teachable. Great leaders continually value their employees' contributions and aptitude to make them feel safe and smart.

\section{5. "That is not my fault."}

When trouble starts most of the time no one wants to take responsibility for the error; however the great leaders always take the front line as he or she feel responsible for team's actions. Best leaders do not point fingers, make excuses, or blame others for the mistakes, on the other hand, demonstrates accountability, and cheers the team toward a solution and work on a plan to assure success (Price 2012). As Henry Ford guided, "Don't find fault, find a remedy."

\section{6. "I'll do it myself."}

No one can do everything by themselves, and especially leadership is not a solo act. The higher the person rises in a corporate position, the less is done as an individual contributor; instead leaders contribute through and by others. The aim is to place the right employees in the right position to perform accurately and empower them to succeed (Price, 2012).

\section{7. "Failure is not an option."}

According to Price (2012), this statement indicates that mistakes are not allowed thereby causes fear into followers, limit creativity, and impedes innovation. Great leaders permit and even encourage their subordinates to fall forward; to learn from mistakes, mishaps into stepping stones. "That is why Thomas J. Watson, founder of IBM, advised, 'The way to succeed is to double your failure rate.' Alternatively, as Arianna Huffington says, 'Failure is not the opposite of success; it is part of success." Nelson Mandela also says, "The greatest glory in living lies not in ever falling, but in rising every time we fall."

\section{8. "That is not the method we use around here."}

Successful leaders realize that their way is not always the best way and are passionate about finding a better method of doing something; therefore, leaders are innovators where they value employees who demonstrate 
creative thinking, ingenuity, flexibility, and problem-solving skills. In another word, great leaders are openminded and always look for a better technique for achieving success. In an event if a leader disagrees with someone's notion, he or she should not reject the idea instead say, that is an interesting view, how would that work? Alternatively, that is a different and new approach, why don't we discuss the advantage and disadvantage of this method.

\section{9. "I do not care."}

If leadership is about caring for others then how can a leader say "I do not care?" In fact, caring attitude distinguishes successful leaders from non-leaders. Great leaders are supportive and always encourage others for their efforts toward achieving a common goal.

\section{It is impossible}

A great leader never uses this statement. This proclamation discourages moving forward and halts creativity that is the opposite of leadership characteristics. This expression in response to an idea or action shuts down any possibility of it ever happening. Trust and self-confidence go hand-in-hand with leadership. Therefore, Leaders may say it is a difficult task, but we have the determination and the willpower as a team of creative minds that will overcome any challenges. According to Nelson Mandela, "It always seems impossible until it is done."

\section{The 5 Levels of Leadership}

John Maxwell in his book in the title of "The Five Levels of Leadership" explores the different stages of leadership. Maxwell explains the advantages, disadvantages and the best behaviors for each level. He further describes the principles that aid a leader in moving up to the subsequent stage, and their association with the laws of leadership (Maxwell, 2013)

\section{Position: having the "Right" as entry level}

Maxwell indicates that position is the lowest level of leadership as he calls it the entry level. Those individuals that achieve only to this level may be bosses, and will not be considered as leaders. They have subordinates, not team members. They depend on rules, regulations, policies, and organization charts to control their people. In this level, people will only follow them because they have to within the stated limitations of their authority. The position level is the only level that does not require ability and effort to achieve. Anyone can be appointed to a position. Thereby, the position is a fine starting point, but every leader should aspire to grow beyond this entry Level (Maxwell, 2013).

\section{Permission: an Influence Level by Relationship}

Moving up from position level to Permission is the first real step into leadership. Leadership is the influence that is built on relationship, thereby, when a leader learns to function on the Permission level, followers not only acts by orders but also start to follow. Therefore, people follow because they want to since the leader begins to influence members with the relationship, not just position. When leader display caring for their followers, include them in decision making, value their opinion, and build trust, and then the followers begin to work together with their leader as a team that energizes the entire working environment (Maxwell, 2013).

\section{Production by Results}

In production level, the leader makes a significant impact on an organization by generating results. The leader in this level is productive and able to help the team members produce as well. Production level cannot be faked because it shows if a leader is truly producing for the organization by adding to its bottom line (whatever that may be), or failing to do so. For this reason, some people never move up from Level 2 Permission to Level 3 Production because they cannot seem to produce results. People incapable of producing results usually lack the self-discipline, work ethic, organization, or skills to be productive. However, if one desires to go to higher levels 
of leadership, he/she simply has to produce and show result; there is no other way around it. Therefore, people follow the leader because of what leader has done for the organization (Maxwell, 2013).

\section{People Development through Reproduction}

In this level, leaders transition from producers to developers. Leaders must be able to develop their people because they are organization's most substantial asset.

Good leaders devote their time, energy, money, and thinking into growing others as leaders. Maxwell further indicates that leaders on the people development level of leadership change their emphasis from the production attained by the members to the growth of their potential. Furthermore, leaders put only 20 percent of their emphasis on their personal productivity whereas placing 80 percent of the focus on developing and leading team members. Therefore, people follow the leader because what the leader has done for them (Maxwell, 2013).

\section{The Pinnacle, the Respect Level of Leadership}

It is rare and only very few reach this level, the Pinnacle. In this level leader not only well experienced in leading on the other four steps but nonetheless it also requires both a high degree of talent and a certain amount of natural leadership skill. The individuals, who reach Level Five, The Pinnacle, lead extremely well for an extended period that they form a heritage of leadership in the organization they serve and they stand out from everyone else.

Leadership at this high level boosts the entire organization and creates an environment that benefits everyone in it, contributing to their success. Greatest leaders late in their careers reach the Pinnacle level where they are reproducing other leaders and make the biggest impact on their lives. Also, they lift up as many leaders as they can with gratitude and humility, tackle as many significant challenges as possible, and extend their influence to make a positive difference beyond their organization and industry. Thereby, people follow because of who the leader is and what he represents (Maxwell, 2013).

\section{Discussion}

The article provides significant steps in behavior modification that will help executives and managers and those of whom seeking leadership position to grasp and acquire the maximum benefit from the subject of leadership. The review article has emphasized on the ten most dynamic behavior any leader must inherit to influence others as a leader. The leadership factors that create influence are within the letters that form the word leadership. Leaders must be great listeners to communicate effectively. Leaders are enthusiastic when they acquire achievements. Aspiring leaders have high ambitions and goal thriving to achieve with an enormous desire and make tough decisions with accountable. Effective leaders empower and encourage team members by supporting and giving them greater responsibilities. Also, leaders are responsible for their actions and help the team to build and maintain effective interpersonal relationships. Great leaders are humble and elevate everyone with their humility by making others feel valued. Leaders inspire team members to perform beyond what's expected of them by motivating them with honesty and truthfulness. True leaders are capable of planning ahead and prepare for the unknown.

Based on the above factors as evident by literature review the leadership is simply defined as:

"LEADERSHIP: Is a position to Listen with Enthusiasm, having an Aspiring mind to be able to make a Decisive action, Empower and Encourage others in a Responsible, Supportive and Humble manner by Inspiring the team to achieve set goals as Planned."

To become an effective leader and sustain the leadership position, one must treat others as they would like to be treated. Therefore, leaders must avoid certain words and phrases that might be injurious to others. For example, I am in charge or the boss, you're lucky to have this job, I want results, not relationships, I know everything, that's not my fault, I'll do it myself, failure is not an option, That's not the way we do it here, I don't care, and It is impossible. Use of these expressions generate a negative effect and deter the main factor of leadership known as an influence (Smith, 2014). It should be clear that leader must always stay positive and follow the ten behavioral factors and avoid any negativity to influence others and win their loyalty. 

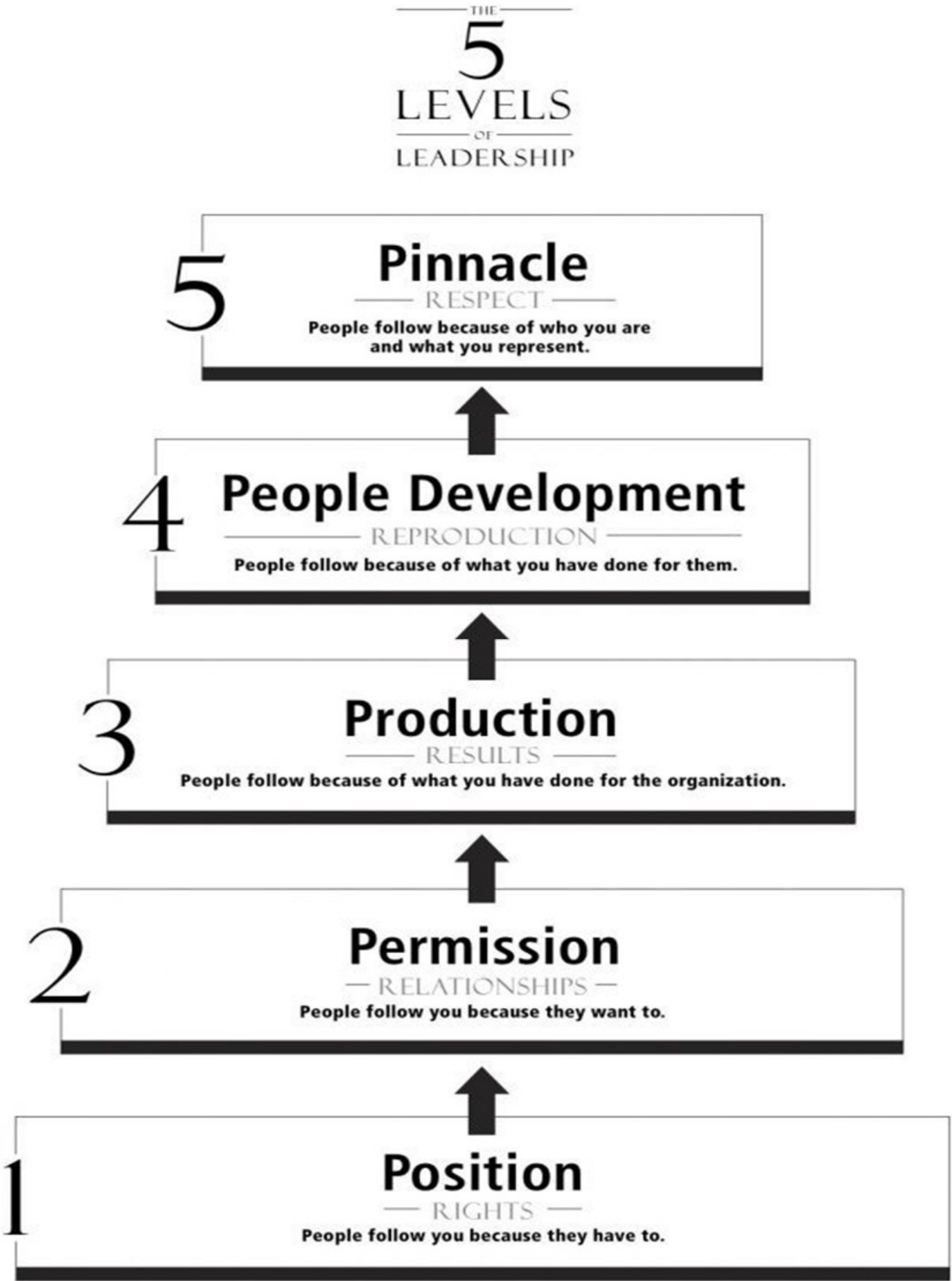

Source: THE 5 LEVELS OF LEADERSHIP

Nov. 22, 2013, http://www.johnmaxwell.com/blog/the-5-levels-of-leadership 
Finally, the five levels of Leadership by John C. Maxwell have been demonstrating the greatest stepping stone for many leaders. Maxwell implies that a leader in a level one, the position level, is a boss, not a leader since he or she has occupied the position without influencing others. Leaders must go beyond the position level to gain relationship and transition to permission level that is the first step toward leadership. In this level leader includes others in decision making and displays a caring attitude thereby gaining loyalty and influence. Maxwell discusses the production level as level 3 of leadership where the leaders generate a result. Leaders not only produce but also assist the team in generating results as well. Leader exhibiting self-discipline, work ethic, organization or skills and experience are capable of producing results. Effective leaders do not stop at this point as they should transform from level 3 to level 4, people development by reproduction. In this level, Maxwell explains the transition from producers to developers. Since people are the most valuable assets, leaders must be able to cultivate them by devoting their time, energy, money, and intellectual capacity into growing others as leaders. Finally, the leaders based on the skills and experience years of devotion to leadership from level 1 to level 4 may be able to reach the pinnacle level as level 5. The individuals, who reach Level 5, The Pinnacle, lead extremely well for an extended period that they build a legacy of leadership in the organization they serve and they are conspicuous among others.

Leaders must develop positive behavior and distinguishing factors to influence team members. Leadership is influence thereby people follow leaders based on desire, relationship, loyalty, ability to produce results, developing peoples' potential and respect.

\section{Limitation}

The review is based on authors experience and consideration of the literature on secondary data in providing the information. The author's opinion is supported by the examination of the articles as referenced. The quantitative research needs to be conducted to obtain the primary information in support of the study to solidify the argument. Therefore, further study is required through a scientific data collection from the organizational members to analyze and compare the outcome to substantiate the notion.

\section{Conclusion}

Leadership is defined in a simple but yet effective manner through the behavior factors that influence others and produce the greatest result. The study displays a genuine definition of leadership through the letters making up the word, "leadership", that is most practical in the modern day organizational settings.

Furthermore, successful leaders recognize the influence of spoken words and phrases as well as its impact on emotions and minds of society. Consequently, great leaders frequently use positive and optimistic phrases when speaking with their members of their team. Leaders should refrain from negativity and use of damaging statements that has the potential for demotivation and sever the relationship as the building block of influence.

Lastly, the five levels of Leadership by John C. Maxwell shed the light on becoming a true leader through basic steps that are discussed in an understanding manner. It indicated that people should follow leaders out of a desire not because they have to. Furthermore, no one can stay at a particular level and sustain leadership. Leaders must strive to move from levels in sequence as provided.

\section{References}

Atwater, E., (1992). I Hear You. (Rev. ed.). Pacific Grove, Ca.: Walker.

Cohn, H. (2015) Characteristics of Good Leaders. Online: http://www.leadershipexpert.co.uk/characteristicsgood-leaders.html Retrieved: October 2015. 
Eikenberry K., (2010), Eight Supportive Behaviors Every Coach (and Person) Should Use. July 5, 2010. http://blog.kevineikenberry.com/leadership-supervisory-skills/eight-supportive-behaviors-every-coach-andperson-should-use/\#sthash.Y7US37ey.dpuf Retrieved Sep. 2015.

Economy p., (2014) “The 9 Traits That Define Great Leadership,” Online: http://www.inc.com/petereconomy/the-9-traits-that-define-great-leadership.html Retrieved Sep., 2015.

Geoffrey Webb, (2010), THINGS LEADERS NEED TO TAKE, May 25, 2010, GEOFF WEBB: http://geoffreywebb.com/2010/05/25/3-things-leaders-need-to-take/ Retrieved Oct 2015.

Guthrie, D. (2012), Creative Leadership: Humility and Being Wrong. Online article:

http://www.forbes.com/sites/dougguthrie/2012/06/01/creative-leadership-humility-and-being-wrong/ Retrieved Sep. 2015.

Heathfield M. S., Leadership Inspiration: 10 Leadership Success Secrets. Online: http://humanresources.about.com/od/leadership/a/leader_inspire.htm Retrieved Oct 2015.

Hopkin R.M. (2015), Great Leaders are Made, Not Born; February 21, 2015, Online article: http://leadonpurposeblog.com/2015/02/21/great-leaders-are-made-not-born/ Retrieved Sep. 2015.

Hunsaker, P., \& Allessandra, A., (1986). The art of managing people. New York: Simon \& Schuster Inc.

Hyatt M., (2012), HOW REAL LEADERS DEMONSTRATE ACCOUNTABILITY March 22, 2012, Online: http://michaelhyatt.com/leadership-and-accountability.html Retrieved Oct. 2015.

Leadership and influence: 10 Traits of Effective Leaders posted on January 17, 2012, Online: http://www.leadershipandinfluenceblog.com/10-traits-of-effective-leaders/ Retrieved Oct. 2015.

Leadership - The Link Between Planning \& Doing. Online: http://work911.com/articles/leaddo.htm Lucia, A., (1997). Leaders know how to focus. HR Focus, 74 (4), 25.

MacDonald, B. (2011), The Power of the Powerful is to Empower the Powerless, posted on June 13, 2011, online: http://bobmaconbusiness.com/?p=2125 Retrieved Sep., 2015.

Maxwell C.J. (2013), THE 5 LEVELS OF LEADERSHIP Online: http://www.johnmaxwell.com/blog/the-5levels-of-leadership Retrieved Sep. 2015.

McCann D., (2011) LEADERSHIP IS ALL ABOUT ENTHUSIASM online:

<a href="http://blog.deiricmccann.com/2011/05/leadership-enthusiasm/">LEADERSHIP IS ALL ABOUT ENTHUSIASM</a> Retrieved Oct. 2015.

Miller, R., QUALITIES OF LEADERSHIP PART 4: INFLUENTIAL AND DECISIVE, “an excerpt from Management Training by the Book series.": Online: http://www.thetrainingbank.com/qualities-of-leadershippart-4/ Retrieved Sept. 2015.

Mills Q. (2005), The Importance of Leadership: How to Lead, How to Live.

Northouse P. (2010), Leadership: Theory and Practice (5 $5^{\text {th }}$ ed.). Thousand Oaks, CA: Sage P. 1-4.

Planning \& Organizing online article: http://www.thecompleteleader.org/planning-organizing. Retrieved Oct. 2015.

Price D. (2012), Well Said!: Presentations and Conversations That Get Results. AMACOM (August 22, 2012). 
Robbins S., Coulter M., (2009), Management (tenth ed.). Upper Saddle River, NJ: Prentice-hall p. 386-404.

Rosenbach, W., Sashkin, M., Harburg, F., (1996). The leadership profile: On becoming a better leader. Seabrook, Md., Du Cochon Press.

Rynders G. (1999), LISTENING AND LEADERSHIP: A STUDY ON THEIR RELATIONSHIP.

Sanborn M., (2012) Leadership Books and Tools Online: http://www.marksanborn.com/blog/the-decisive-leader/ Retrieved Oct. 2015.

Scott S., Demand Media: The 10 Effective Qualities of a Team Leader Online: http://smallbusiness.chron.com/10-effective-qualities-team-leader-23281.html Retrieved Sep. 2015.

Smith J. (2014) Online: http://www.businessinsider.com/successful-leaders-never-say-these-things-2014-9, retrieved October 10, 2015.

The Top 10 Leadership Qualities (2014) Online: http://www.comparebusinessproducts.com/briefs/top-10leadership-qualities. Retrieved Oct. 2015. 